\title{
Effects of hypoxia and subsequent recovery on turbot Scophthalmus maximus: hormonal changes and anaerobic metabolism
}

\author{
K. Pichavant ${ }^{1, *}$, V. Maxime ${ }^{1}$, M. T. Thébault ${ }^{2}$, H. Ollivier ${ }^{1}$, J. P. Garnier ${ }^{3,4}{ }^{\text {, }}$ \\ B. Bousquet ${ }^{3,4}$, M. Diouris ${ }^{5}$, G. Boeuf ${ }^{6}$, G. Nonnotte ${ }^{1}$ \\ ${ }^{1}$ Laboratoire de Biologie et Physiologie Cellulaires, UFR Sciences et Techniques, Université de Bretagne Occidentale, \\ BP 809, 29285 Brest Cédex, France \\ ${ }^{2}$ LEMAR, UMR CNRS 6539, IUEM, Université de Bretagne Occidentale, Place Copernic, Technopôle Brest-Iroise, \\ 29280 Plouzané, France \\ ${ }^{3}$ Laboratoire de Biochimie et de Neuroendocrinologie, Hôpital Saint-Louis, 75475 Paris Cédex 10, France \\ ${ }^{4}$ Faculté de Pharmacie Paris V, Biochimie Métabolique et Clinique, 75006 Paris, France \\ ${ }^{5}$ LEBHAM, Université de Bretagne Occidentale, Place Copernic, Technopôle Brest-Iroise, 29280 Plouzané, France \\ ${ }^{6}$ Laboratoire Arago, Observatoire Océanologique, CNRS/Université Pierre et Marie Curie, 66651 Banyuls-sur-mer, France
}

\begin{abstract}
Hormonal changes, substrate mobilization and energy metabolism were studied in turbot Scophthalmus maximus exposed to 3 hypoxic conditions (oxygen partial pressure in water, $\mathrm{PwO}_{2}=90,60$ and $30 \mathrm{~mm} \mathrm{Hg}$ ) followed by recovery under normoxia. Measurements of the blood $\mathrm{pH}$, total $\mathrm{CO}_{2}$ concentration, arterial oxygen partial pressure, hematocrit, glucose, lactate, and 'stress' hormones (cortisol, adrenaline and noradrenaline) plasmatic concentrations were performed. Highenergy phosphorylated compounds, glycogen, glucose and lactate concentrations were also determined in liver and white muscle tissues. Exposure to 90 or $60 \mathrm{~mm} \mathrm{Hg}$ did not induce any major physiological change, as hyperventilation by itself could compensate for the decrease in water oxygen tension. At $30 \mathrm{~mm} \mathrm{Hg}$, marked increases in cortisol, adrenaline and noradrenaline concentrations, associated with a decrease in blood arterial oxygen partial pressure, were observed. During exposure to $30 \mathrm{~mm} \mathrm{Hg}$, turbot resorted to anaerobic metabolism, resulting in liver glycogen depletion and lactate production. This mechanism appeared to be efficient enough to produce energy, as no significant change in phosphorylated compounds and adenylate energy charges in muscle and liver could be observed. These results indicate an absence of metabolic depression in turbot down to $30 \mathrm{~mm} \mathrm{Hg}$ and confirm the high capacity of this species to cope with low water oxygen tension.
\end{abstract}

KEY WORDS: Hypoxia $\cdot$ Anaerobiosis $\cdot$ Catecholamines $\cdot$ Cortisol $\cdot$ Lactate $\cdot$ Turbot

- Resale or republication not permitted without written consent of the publisher

\section{INTRODUCTION}

Fish exposed to a reduction in ambient oxygen tension respond with attempts to maintain oxygen supply to the tissues and with energy saving strategies. Respiratory and circulatory responses (increase in amplitude and frequency of ventilation combined with bradycar-

*E-mail: karine.pichavant@univ-brest.fr dia) are often the first adaptative mechanisms developed by fish to face hypoxia (Lomholt \& Johansen 1979, Glass et al. 1990, Maxime et al. 1998). However, below a critical oxygen threshold depending on species and determined under standard metabolism conditions, the aerobic energy production decreases. Therefore, to stabilize ATP concentration in muscle, fish mainly resort to a depletion of the creatine phosphate pool via the creatine kinase equilibrium reaction and to anaerobic metabolism (Driedzic \& Hochachka 
1975, Smith \& Heath 1980, Dalla Via et al. 1994). A decrease in the free fatty acid pool in plasma (Mazeaud et al. 1977) and a strategy of metabolic depression, which is important in some species (Van Waversveld et al. 1989, Van Ginneken et al. 1998) have also been reported. Most of these mechanisms are under hormonal control involving catecholamines and cortisol (Kinkead \& Perry 1991, Van Raaij et al. 1996).

Like other benthic flatfish, turbot Scophthalmus maximus is frequently exposed to environmental hypoxic conditions and is therefore a useful model to study the physiological mechanisms developed by fish to face hypoxia. In a previous study (Maxime et al. 2000), we have pointed out that the first strategy of turbot to face hypoxia was an increase in ventilation with, obviously, consequences for blood acid-base equilibrium. Hyperventilation allowed turbot to maintain standard $\mathrm{O}_{2}$ consumption over a wide range of $\mathrm{O}_{2}$ tensions, down to a low critical level of $30 \mathrm{~mm} \mathrm{Hg}$. When hyperventilation could not contribute to maintaining the standard oxygen consumption, turbot resorted to anaerobic metabolism resulting in lactate accumulation in blood and muscle tissue. However, metabolic adaptations as hormonal changes have not been quantified and the question of lactate origin remains. In the present study, lactate origin, energy metabolism and hormonal changes were investigated to elucidate the strategies developed by turbot exposed to different levels of hypoxia and then to normoxic conditions.

\section{MATERIAL AND METHODS}

Fish and conditioning. The experiments were carried out on turbot weighing between 1.5 and $2.5 \mathrm{~kg}$, which were obtained from the experimental hatchery of IFREMER (Plouzané, France). Fish had been reared at IFREMER according to the methods described by Person-Le-Ruyet et al. (1991): the fish were kept in large outdoor circular tanks supplied with running seawater $(34 \%)$ at seasonal temperature $\left(14\right.$ to $\left.18^{\circ} \mathrm{C}\right)$ and fed daily with Gouessant ${ }^{\circledR}$ pelleted food. One week before experimentation, fish were starved and transferred to experimental tanks supplied with a continuous seawater flow $\left(17.0 \pm 0.5^{\circ} \mathrm{C}\right.$ and 34 to $\left.34.5 \%\right)$. During the whole experimental protocol, the fish were unfed.

Experimental protocol. Measurements of arterial $\mathrm{O}_{2}$ partial pressure $\left(\mathrm{PaO}_{2}\right)$, blood acid-base parameters, hematocrit and blood cortisol, adrenaline and noradrenaline concentrations were performed on cannulated fish. After anesthesia by immersion in a 2-phenoxyethanol solution (1/1000), each fish was fitted with a polyethylene catheter (PE-50) chronically inserted into the caudal artery according to the method de- scribed by Nonnotte \& Truchot (1990). Throughout the surgery procedure, gills were flushed with wellaerated seawater containing a low concentration of anesthetic (1/3000). The catheter was filled with a heparinized (250 UI ml-1) saline solution and sealed. Turbot were then transferred to individual experimental boxes $(0.5 \times 0.5 \mathrm{~m}$ and $0.15 \mathrm{~m}$ deep) supplied with running seawater $\left(17^{\circ} \mathrm{C}\right.$ and 34 to $\left.34.5 \%\right)$. Fish were unstressed throughout the experiment beginning 48 to $72 \mathrm{~h}$ after the surgery procedure.

Lots of 6 cannulated fish were then exposed for $6 \mathrm{~h}$ to 1 of the 3 environmental hypoxia levels: $90 \mathrm{~mm} \mathrm{Hg}$ (60\% $\mathrm{O}_{2}$ saturation), $60 \mathrm{~mm} \mathrm{Hg}(40 \%)$, and $30 \mathrm{~mm} \mathrm{Hg}$ $(20 \%)$. Oxygen partial pressure in water $\left(\mathrm{PwO}_{2}\right)$ levels were adjusted by means of an oxygen-depletion system described in Pichavant et al. (2000). In each experimental box, $\mathrm{PwO}_{2}$ was continuously monitored throughout the experiment according to Gaumet et al. (1995). After hypoxia exposure, the water was rapidly aerated (normoxic $\mathrm{PwO}_{2}$ level was reached within $15 \mathrm{~min}$ ) and recovery was monitored for $6 \mathrm{~h}$.

Blood samples were drawn from the dorsal aortic catheter before hypoxia exposure to obtain control values of measured parameters. Then, fish were exposed to 1 of the 3 hypoxic levels, and blood samples were taken after 1, 2, 4 and $6 \mathrm{~h}$. Blood samples were also taken after 1, 2, 4 and $6 \mathrm{~h}$ during the phase involving a return to normoxic conditions.

Two blood samples were taken at each time. The first sample $(350 \mu \mathrm{l})$ was immediately used for the determination of $\mathrm{PaO}_{2}, \mathrm{pH}$ and hematocrit according to the procedures mentioned below. The second sample $(500 \mu \mathrm{l})$ was immediately centrifuged $(10 \mathrm{~min}$ at $600 \times \mathrm{g})$, and plasma was rapidly separated from blood cells, of which $20 \mu \mathrm{l}$ were directly used for the determination of blood total $\mathrm{CO}_{2}$ concentration. Two aliquots of plasma (10 and $300 \mu \mathrm{l}$ ) were stored at $-80^{\circ} \mathrm{C}$ for later measurement of cortisol and catecholamines concentrations respectively.

Determination of lactate and glucose concentrations in plasma, white muscle and liver were performed on uncannulated fish. In these fish, glycogen, ATP, ADP and AMP concentrations were also measured in white muscle and liver, and IMP concentration was determined in white muscle. At least $1 \mathrm{wk}$ before the experiment, the fish were divided into groups of 42 and transferred into experimental tanks $\left(1 \mathrm{~m}^{2}\right.$ Swedishtype tanks with an effective water volume of 450 l) fitted out with the oxygen-depletion system mentioned above. The levels and durations of hypoxia and subsequent recoveries were the same as those imposed on cannulated fish. Blood samples and biopsies (liver and muscle) were carried out on lots of 6 fish that were slightly anesthetized before hypoxia exposure, at 2, 4 and $6 \mathrm{~h}$ during hypoxia exposure and at 2, 4 and $6 \mathrm{~h}$ 
during the phase involving a return to normoxic conditions. Blood samples were obtained by puncture of the caudal artery, immediately centrifuged (10 min at $600 \times$ $g$ ) and plasma was separated into 2 aliquots of $50 \mu \mathrm{l}$ and stored at $-80^{\circ} \mathrm{C}$ for later analyses of lactate and glucose concentrations. Fragments of about $200 \mathrm{mg}$ of white muscle (obtained from the eyed side close to the lateral line) and liver were immediately freezeclamped with aluminum tongs precooled in liquid nitrogen according to Adcock \& Dando (1983) and stored in liquid nitrogen before the extraction procedure.

Analytical procedures. $\mathrm{PaO}_{2}$ was obtained from a Radiometer ${ }^{\circledR}$ E5046 thermostated $\mathrm{PO}_{2}$ cell connected to a Stratkelvin ${ }^{\circledR}$ oxymeter. Arterial pH was measured by means of a Broadley ${ }^{\circledR}$ microflow $\mathrm{pH}$ sensor connected to a Metrohm ${ }^{\circledast} \mathrm{pH}$ meter. A part of this blood aliquot was used to measure hematocrit. Plasma total $\mathrm{CO}_{2}$ concentrations were measured using a Sigma Diagnostics Kit (procedure 132-UV) within 15 min after blood sampling. Plasma cortisol concentrations were determined by specific radioimmunoassay adapted from Lamers et al. (1992). Plasma adrenaline and noradrenaline concentrations were measured by HPLC using an internal standard solution (3,4-dihydrobenzylamine) as according to Letellier et al. (1994). Plasma lactate and glucose concentrations were determined by enzymatic methods (Sigma Diagnostics Kits, procedures 735 and 16-UV respectively).

Pre-weighed muscle and liver samples were powdered in a pre-cooled mortar along with liquid nitrogen and pulverized in chilled perchloric acid $(1 \mathrm{ml}$, $0.9 \mathrm{~N}$ ). The homogenate was weighed and centrifuged at $10000 \times g$ for $5 \mathrm{~min}$ at $4^{\circ} \mathrm{C}$. The supernatant was weighed, the $\mathrm{pH}$ was immediately adjusted to 6.5 with $1 \mathrm{M} \mathrm{K}_{2} \mathrm{CO}_{3}$, and the supernatant was centrifuged again after precipitation. Four aliquots of the supernatant were stored at $-80^{\circ} \mathrm{C}$ for later analyses of lactate $(50 \mu \mathrm{l})$, glucose $(50 \mu \mathrm{l})$, glycogen $(60 \mu \mathrm{l})$ and nucleotide $(50 \mu \mathrm{l})$ concentrations. Lactate and glucose concentrations were determined using the enzymatic methods above mentioned. Glycogen concentration was measured according to an enzymatic method adapted from Carr \& Neff (1984). Concentrations of the nucleotides (ATP, ADP, AMP and IMP) were determined by HPLC. Plasma samples were passed through a Waters ${ }^{\circledR}$ Novopack $\mathrm{C} 18$ column, eluted at a flow rate of $1 \mathrm{ml} \mathrm{min}^{-1}$ using a $0.2 \mathrm{M}$ isocratic $\mathrm{NH}_{4} \mathrm{H}_{2} \mathrm{PO}_{4}$ buffer at $\mathrm{pH} \mathrm{6.1}$, and nucleotides were detected at $254 \mathrm{~nm}$. The adenylate energy charge (AEC) was calculated according to Atkinson (1968): AEC $=\left[\left(\mathrm{ATP}+\frac{1}{2} \mathrm{ADP}\right) /(\mathrm{ATP}+\mathrm{ADP}+\right.$ AMP)].

Statistical analysis. Statistical analyses were conducted using Sigmastat ${ }^{\circledR}$ for Windows (Jandel Scientific). All data are expressed as mean \pm SE. Effects of hypoxia and recovery on measured parameters were tested by a 1-way repeated-measures ANOVA for cannulated fish and by a 1-way ANOVA for uncannulated fish. Significant ANOVA were followed by a post hoc multiple comparisons test versus control group (Bonferroni $t$-test). Differences were considered significant at $\mathrm{p}<0.05$.

\section{RESULTS}

Before hypoxia exposure, blood samples and tissues were taken to determine the initial level of the measured parameters. As no significant differences among the 6 fish in each of the 3 experimental groups were observed, these pre-hypoxic data $(\mathrm{n}=18)$ were pooled to obtain a reliable control value for comparison.

Blood arterial $\mathrm{pH}(\mathrm{pHa})$, total $\mathrm{CO}_{2}$ concentration ([TCO $\left.\left.{ }_{2}\right]\right), \mathrm{PaO}_{2}$ and hematocrit (Ht) were unaffected by exposure to a $90 \mathrm{~mm} \mathrm{Hg} \mathrm{PwO}_{2}$ water (Table 1). These parameters remained unchanged when $\mathrm{PwO}_{2}$ was adjusted to $60 \mathrm{~mm} \mathrm{Hg}$, except $\mathrm{PaO}_{2}$, which decreased significantly during hypoxia exposure and was totally restored $1 \mathrm{~h}$ after the end of the hypoxic phase (Table 1). Exposure for $6 \mathrm{~h}$ to the lowest $\mathrm{PwO}_{2}$ level (30 $\mathrm{mm} \mathrm{Hg}$ ) induced marked changes in these parameters. An increase in pHa (+ $0.11 \mathrm{pH}$ unit), followed by a significant acidosis, was observed (Fig. 1A). [ $\left.\mathrm{TCO}_{2}\right]$ and $\mathrm{PaO}_{2}$ decreased gradually and reached their minimal value respectively after 4 and $6 \mathrm{~h}$ (Fig. 1B,C). Ht increased significantly from $12.8 \pm 1.4 \%$ in normoxia up to $18.3 \pm 2.2 \%$ after $4 \mathrm{~h}$ (Fig. 1D). During the subsequent recovery, only pHa was not restored after $6 \mathrm{~h}$.

Plasma adrenaline $[\mathrm{A}]$, noradrenaline [NA] and cortisol [CORT] concentrations were unaffected by exposure to 90 and $60 \mathrm{~mm} \mathrm{Hg}$ (Table 2). However, when the fish were exposed to $30 \mathrm{~mm} \mathrm{Hg}$, [A], [NA] and [CORT] increased almost immediately after the lowering of $\mathrm{PwO}_{2}$ (Fig. 2A-C respectively). During the subsequent recovery, [A] and [NA] were restored within $1 \mathrm{~h}$ whereas [CORT] remained significantly high compared to the control value even after $6 \mathrm{~h}$.

Plasma, liver and muscle lactate concentrations are given in Table 3 for fish exposed to 90 and $60 \mathrm{~mm} \mathrm{Hg}$. Only a slight but significant increase in muscle lactate level was observed when fish were exposed to $60 \mathrm{~mm}$ Hg. During the subsequent recovery, the muscle lactate concentration was totally restored after $6 \mathrm{~h}$. The exposure to the $30 \mathrm{~mm} \mathrm{Hg}$ treatment induced a gradual and marked increase in plasma, muscle and liver lactate concentrations at once (Fig. 3A-C respectively). During the subsequent recovery, plasma and tissue lactate levels decreased as soon as the hypoxic treatment was stopped. Plasma and liver lactate concentrations were close to the normoxic values after $6 \mathrm{~h}$ 
of recovery, whereas muscle level remained significantly higher at this time.

Plasma, liver and muscle glucose concentrations in a similar way to muscle and liver glycogen concentrations remained steady throughout the 90 and $60 \mathrm{~mm}$ $\mathrm{Hg}$ periods (Tables 4 \& 5 for glucose and glycogen levels respectively). Exposure to $30 \mathrm{~mm} \mathrm{Hg}$ induced a significant increase in plasma glucose level after $4 \mathrm{~h}$
(Table 4) and a marked liver glycogen depletion after $6 \mathrm{~h}$ (Table 5). The plasma glucose concentration was back to the control level $2 \mathrm{~h}$ after the end of the hypoxic phase.

In muscle, the initial values of nucleotides were (in $\mu \mathrm{mol} \mathrm{g}{ }^{-1}$ fresh weight): $6.79 \pm 0.55$ (ATP), $0.75 \pm 0.07$ (ADP), $0.06 \pm 0.01$ (AMP) and $0.10 \pm 0.01$ (IMP). In liver, the initial values of nucleotides were: $1.99 \pm 0.29$

Table 1. Blood arterial $\mathrm{pH}(\mathrm{pHa})$, blood total $\mathrm{CO}_{2}$ concentration $\left(\left[\mathrm{TCO}_{2}\right]\right)$, blood arterial oxygen partial pressure $(\mathrm{PaO})$ and hematocrit (Ht) measured on cannulated fish at time 0 (normoxia), 1, 2, 4 and $6 \mathrm{~h}$ during the exposure at 90 and $60 \mathrm{~mm} \mathrm{Hg}$, and 1, 2, 4 and $6 \mathrm{~h}$ after the end of hypoxia (R1, R2, R4 and R6). Means \pm SE (n = 18 at $t=0$ and $6 \mathrm{~h}$ at the other sample times). ${ }^{*}$ Values significantly different from control data at $\mathrm{p}<0.05$. NS = no significant difference and $\mathrm{S}=$ significant difference

\begin{tabular}{|c|c|c|c|c|c|c|c|c|c|c|}
\hline Time (h) & 0 & 1 & 2 & 4 & 6 & R1 & $\mathrm{R} 2$ & $\mathrm{R} 4$ & R6 & \\
\hline \multicolumn{11}{|l|}{$90 \mathrm{~mm} \mathrm{Hg}$} \\
\hline PHa & $\begin{array}{r}7.98 \\
\pm 0.02\end{array}$ & $\begin{array}{r}8.00 \\
\pm 0.01\end{array}$ & $\begin{array}{r}8.00 \\
\pm 0.02\end{array}$ & $\begin{array}{r}8.02 \\
\pm 0.01\end{array}$ & $\begin{array}{r}8.02 \\
\pm 0.01\end{array}$ & $\begin{array}{r}7.99 \\
\pm 0.01\end{array}$ & $\begin{array}{r}8.00 \\
\pm 0.02\end{array}$ & $\begin{array}{r}7.98 \\
\pm 0.01\end{array}$ & $\begin{array}{r}8.02 \\
\pm 0.01\end{array}$ & NS \\
\hline $\begin{array}{l}{\left[\mathrm{TCO}_{2}\right]} \\
\left(\mathrm{mmol} \mathrm{l}^{-1}\right)\end{array}$ & $\begin{array}{r}8.11 \\
\pm 0.52\end{array}$ & $\begin{array}{r}7.99 \\
\pm 0.36\end{array}$ & $\begin{array}{r}8.02 \\
\pm 0.68\end{array}$ & $\begin{array}{r}7.96 \\
\pm 0.47\end{array}$ & $\begin{array}{r}7.92 \\
\pm 0.42\end{array}$ & $\begin{array}{r}7.99 \\
\pm 0.53\end{array}$ & $\begin{array}{r}8.00 \\
\pm 0.52\end{array}$ & $\begin{array}{r}7.98 \\
\pm 0.41\end{array}$ & $\begin{array}{r}8.02 \\
\pm 0.42\end{array}$ & NS \\
\hline $\begin{array}{l}\mathrm{PaO}_{2} \\
(\mathrm{~mm} \mathrm{Hg})\end{array}$ & $\begin{array}{l}32.6 \\
\pm 2.7\end{array}$ & $\begin{array}{r}29.5 \\
\pm 3.5\end{array}$ & $\begin{array}{r}27.5 \\
\pm 4.2\end{array}$ & $\begin{array}{r}29.8 \\
\pm 3.8\end{array}$ & $\begin{array}{r}28.7 \\
\pm 4.9\end{array}$ & $\begin{array}{r}28.5 \\
\pm 4.3\end{array}$ & $\begin{array}{r}24.5 \\
\pm 5.2\end{array}$ & $\begin{array}{r}29.8 \\
\pm 4.5\end{array}$ & $\begin{array}{r}27.5 \\
\pm 5.1\end{array}$ & NS \\
\hline Ht (\%) & $\begin{array}{r}12.8 \\
\pm 1.4\end{array}$ & $\begin{array}{r}13.7 \\
\pm 1.8\end{array}$ & $\begin{array}{r}13.0 \\
\pm 1.5\end{array}$ & $\begin{array}{r}12.4 \\
\pm 0.7\end{array}$ & $\begin{array}{r}12.2 \\
\pm 0.6\end{array}$ & $\begin{array}{l}11.0 \\
\pm 1.4\end{array}$ & $\begin{array}{r}12.0 \\
\pm 2.2\end{array}$ & $\begin{array}{r}11.5 \\
\pm 1.9\end{array}$ & $\begin{array}{l}12.2 \\
\pm 1.9\end{array}$ & NS \\
\hline \multicolumn{11}{|l|}{$60 \mathrm{~mm} \mathrm{Hg}$} \\
\hline PHa & $\begin{array}{r}7.98 \\
\pm 0.02\end{array}$ & $\begin{array}{r}8.01 \\
\pm 0.03\end{array}$ & $\begin{array}{r}8.01 \\
\pm 0.02\end{array}$ & $\begin{array}{r}7.98 \\
\pm 0.01\end{array}$ & $\begin{array}{r}7.95 \\
\pm 0.04\end{array}$ & $\begin{array}{r}7.96 \\
\pm 0.01\end{array}$ & $\begin{array}{r}7.97 \\
\pm 0.01\end{array}$ & $\begin{array}{r}7.99 \\
\pm 0.02\end{array}$ & $\begin{array}{r}7.98 \\
\pm 0.01\end{array}$ & NS \\
\hline $\begin{array}{l}{\left[\mathrm{TCO}_{2}\right]} \\
\left(\mathrm{mmol} \mathrm{l}^{-1}\right)\end{array}$ & $\begin{array}{r}8.11 \\
\pm 0.52\end{array}$ & $\begin{array}{r}7.89 \\
\pm 0.45\end{array}$ & $\begin{array}{r}7.92 \\
\pm 0.48\end{array}$ & $\begin{array}{r}7.80 \\
\pm 0.47\end{array}$ & $\begin{array}{r}7.61 \\
\pm 0.49\end{array}$ & $\begin{array}{r}7.86 \\
\pm 0.48\end{array}$ & $\begin{array}{r}7.96 \\
\pm 0.49\end{array}$ & $\begin{array}{r}7.90 \\
\pm 0.34\end{array}$ & $\begin{array}{r}8.12 \\
\pm 0.36\end{array}$ & NS \\
\hline $\begin{array}{l}\mathrm{PaO}_{2} \\
(\mathrm{~mm} \mathrm{Hg})\end{array}$ & $\begin{array}{l}32.6 \\
\pm 2.7\end{array}$ & $\begin{array}{l}23.4^{*} \\
\pm 4.1\end{array}$ & $\begin{array}{l}20.6^{*} \\
\pm 3.2\end{array}$ & $\begin{array}{l}21.2^{*} \\
\pm 2.5\end{array}$ & $\begin{array}{l}24.5^{*} \\
\pm 4.1\end{array}$ & $\begin{array}{r}28.3 \\
\pm 2.6\end{array}$ & $\begin{array}{r}29.2 \\
\pm 3.9\end{array}$ & $\begin{array}{l}33.9 \\
\pm 4.2\end{array}$ & $\begin{array}{l}34.6 \\
\pm 1.5\end{array}$ & $\mathrm{~S}$ \\
\hline Ht (\%) & $\begin{array}{r}12.8 \\
\pm 1.4\end{array}$ & $\begin{array}{l}13.0 \\
\pm 1.7\end{array}$ & $\begin{array}{r}12.8 \\
\pm 1.5\end{array}$ & $\begin{array}{r}12.8 \\
\pm 0.9\end{array}$ & $\begin{array}{r}11.9 \\
\pm 0.6\end{array}$ & $\begin{array}{r}11.0 \\
\pm 0.4\end{array}$ & $\begin{array}{r}11.4 \\
\pm 0.5\end{array}$ & $\begin{array}{l}12.2 \\
\pm 1.1\end{array}$ & $\begin{array}{r}11.8 \\
\pm 0.2\end{array}$ & NS \\
\hline
\end{tabular}

Table 2. Plasma adrenaline [A], noradrenaline [NA] and cortisol [CORT] concentrations measured on cannulated fish at time 0 (normoxia), 1, 2, 4 and $6 \mathrm{~h}$ during the exposure at 90 and $60 \mathrm{~mm} \mathrm{Hg}$, and 1, 2, 4 and $6 \mathrm{~h}$ after the end of hypoxia (R1, R2, R4 and R6). Means $\pm \mathrm{SE}(\mathrm{n}=18$ at $t=0$ and $6 \mathrm{~h}$ at the other sample times for cortisol; $\mathrm{n}=12$ at $t=0$ and $4 \mathrm{~h}$ at the other sample times for adrenaline and noradrenaline). NS = no significant difference

\begin{tabular}{|c|c|c|c|c|c|c|c|c|c|c|}
\hline Time (h) & 0 & 1 & 2 & 4 & 6 & R1 & $\mathrm{R} 2$ & $\mathrm{R} 4$ & R6 & \\
\hline $\begin{array}{l}90 \mathbf{~ m m ~ H g} \\
{[\mathrm{A}]} \\
\left(\mathrm{nmol} \mathrm{l} \mathrm{l}^{-1}\right)\end{array}$ & $\begin{array}{r}1.05 \\
\pm 0.48\end{array}$ & $\begin{array}{r}2.46 \\
\pm 1.34\end{array}$ & $\begin{array}{r}0.55 \\
\pm 0.05\end{array}$ & $\begin{array}{r}0.28 \\
\pm 0.09\end{array}$ & $\begin{array}{r}1.92 \\
\pm 0.88\end{array}$ & $\begin{array}{r}1.20 \\
\pm 0.55\end{array}$ & $\begin{array}{r}0.56 \\
\pm 0.07\end{array}$ & $\begin{array}{r}1.78 \\
\pm 0.37\end{array}$ & $\begin{array}{r}0.59 \\
\pm 0.24\end{array}$ & NS \\
\hline $\begin{array}{l}{[\mathrm{NA}]} \\
\left(\mathrm{nmol} \mathrm{l}^{-1}\right)\end{array}$ & $\begin{array}{r}0.62 \\
\pm 0.17\end{array}$ & $\begin{array}{r}1.17 \\
\pm 0.87\end{array}$ & $\begin{array}{r}0.70 \\
\pm 0.30\end{array}$ & $\begin{array}{r}0.65 \\
\pm 0.35\end{array}$ & $\begin{array}{r}1.27 \\
\pm 0.43\end{array}$ & $\begin{array}{r}1.45 \\
\pm 0.07\end{array}$ & $\begin{array}{r}0.86 \\
\pm 0.09\end{array}$ & $\begin{array}{r}0.57 \\
\pm 0.06\end{array}$ & $\begin{array}{r}0.68 \\
\pm 0.06\end{array}$ & NS \\
\hline $\begin{array}{l}\text { [CORT] } \\
\left(\mathrm{ng} \mathrm{ml}^{-1}\right)\end{array}$ & $\begin{array}{r}14.4 \\
\pm 4.6\end{array}$ & $\begin{array}{r}23.9 \\
\pm 11.3\end{array}$ & $\begin{array}{r}26.6 \\
\pm 15.8\end{array}$ & $\begin{array}{r}25.5 \\
\pm 11.9\end{array}$ & $\begin{array}{l}20.7 \\
\pm 9.9\end{array}$ & $\begin{array}{l}19.8 \\
\pm 6.0\end{array}$ & $\begin{array}{l}20.1 \\
\pm 5.2\end{array}$ & $\begin{array}{r}22.1 \\
\pm 12.3\end{array}$ & $\begin{array}{r}18.8 \\
\pm 14.4\end{array}$ & NS \\
\hline $\begin{array}{l}60 \mathbf{~ m m ~ H g} \\
{[\mathrm{A}]} \\
\left(\mathrm{nmol} \mathrm{l}^{-1}\right)\end{array}$ & $\begin{array}{r}1.05 \\
\pm 0.48\end{array}$ & $\begin{array}{r}0.99 \\
\pm 0.53\end{array}$ & $\begin{array}{r}1.64 \\
\pm 0.65\end{array}$ & $\begin{array}{r}1.727 \\
\pm 0.2\end{array}$ & $\begin{array}{r}4.48 \\
\pm 2.42\end{array}$ & $\begin{array}{r}0.53 \\
\pm 0.06\end{array}$ & $\begin{array}{r}0.86 \\
\pm 0.38\end{array}$ & $\begin{array}{r}0.80 \\
\pm 0.45\end{array}$ & $\begin{array}{r}0.80 \\
\pm 0.35\end{array}$ & NS \\
\hline $\begin{array}{l}{[\mathrm{NA}]} \\
\left(\mathrm{nmol} \mathrm{l}^{-1}\right)\end{array}$ & $\begin{array}{r}0.62 \\
\pm 0.17\end{array}$ & $\begin{array}{r}1.23 \\
\pm 0.40\end{array}$ & $\begin{array}{r}1.60 \\
\pm 0.65\end{array}$ & $\begin{array}{r}2.24 \\
\pm 0.63\end{array}$ & $\begin{array}{r}3.98 \\
\pm 1.66\end{array}$ & $\begin{array}{r}0.42 \\
\pm 0.01\end{array}$ & $\begin{array}{r}0.49 \\
\pm 0.15\end{array}$ & $\begin{array}{r}0.56 \\
\pm 0.14\end{array}$ & $\begin{array}{r}0.66 \\
\pm 0.08\end{array}$ & NS \\
\hline $\begin{array}{l}{[\mathrm{CORT}]} \\
\left(\mathrm{ng} \mathrm{ml}^{-1}\right)\end{array}$ & $\begin{array}{r}14.4 \\
\pm 8.6\end{array}$ & $\begin{array}{r}31.1 \\
\pm 23.8\end{array}$ & $\begin{array}{r}45.0 \\
\pm 26.0\end{array}$ & $\begin{array}{r}12.3 \\
\pm 7.9\end{array}$ & $\begin{array}{r}48.0 \\
\pm 25.9\end{array}$ & $\begin{array}{r}32.5 \\
\pm 16.5\end{array}$ & $\begin{array}{r}20.3 \\
\pm 12.2\end{array}$ & $\begin{array}{r}45.6 \\
\pm 27.3\end{array}$ & $\begin{array}{r}38.3 \\
\pm 12.8\end{array}$ & NS \\
\hline
\end{tabular}


(ATP), $0.61 \pm 0.10(\mathrm{ADP})$ and $0.06 \pm 0.02$ (AMP). No change in liver and muscle nucleotides concentrations was observed throughout the exposure at 90,60 and $30 \mathrm{~mm} \mathrm{Hg}$ and during the subsequent recovery, so the AEC was unchanged during the experiment (Table 6).
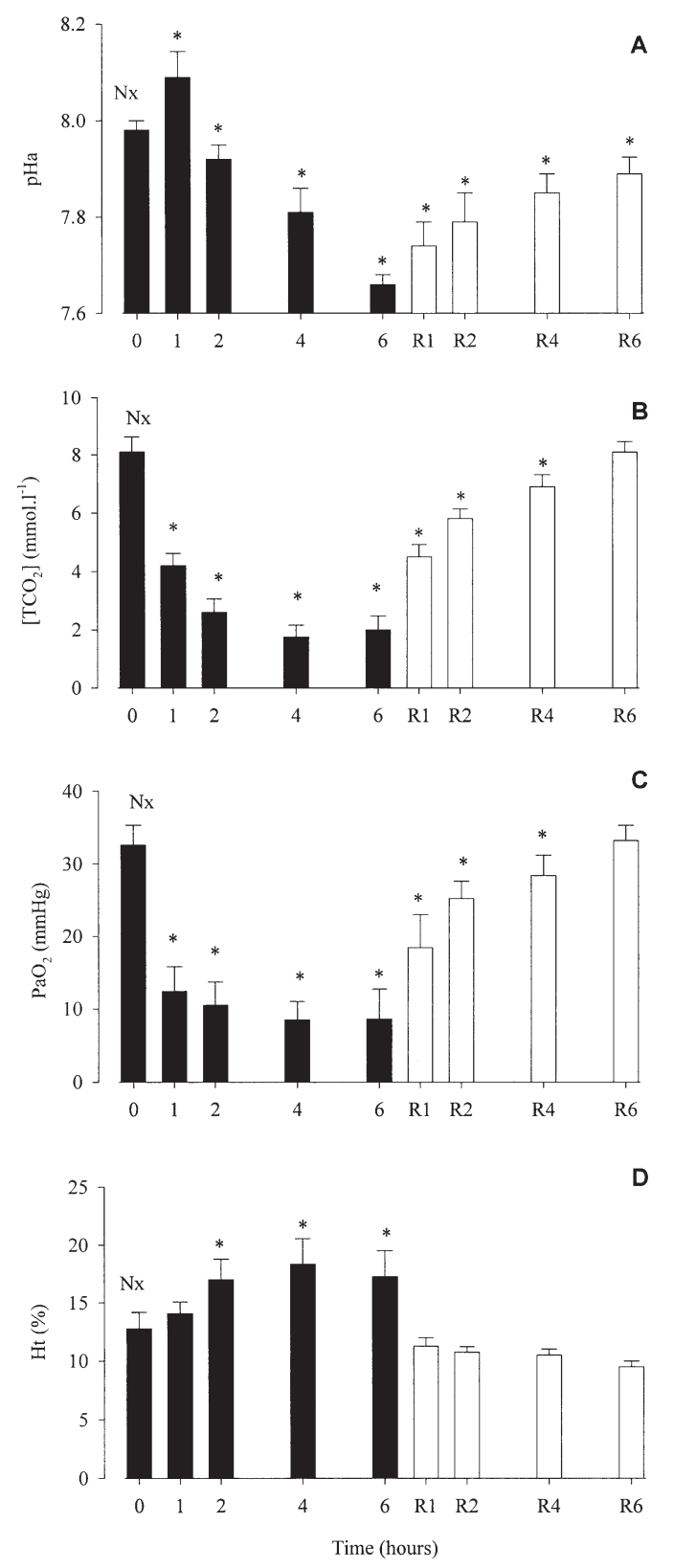

Fig. 1. Blood arterial $\mathrm{pH}(\mathrm{pHa})$, blood total $\mathrm{CO}_{2}$ concentration $\left[\mathrm{TCO}_{2}\right]$, blood arterial oxygen partial pressure $\left(\mathrm{PaO}_{2}\right)$ and hematocrit $(\mathrm{Ht})$ measured on cannulated fish at time $0(\mathrm{Nx}=$ normoxia), 1, 2, 4 and $6 \mathrm{~h}$ during the exposure at $30 \mathrm{~mm} \mathrm{Hg}$ $(\square)$, and 1, 2, 4 and $6 \mathrm{~h}$ after the end of hypoxia ( $\square$ ). Means \pm $\mathrm{SE}$ ( $\mathrm{n}=18$ at $t=0$ and $6 \mathrm{~h}$ at the other sample times). *Values significantly different from control data at $\mathrm{p}<0.05$

\section{DISCUSSION}

As surgery was used to obtain some blood parameters, it could be considered that stress reactions would create some perturbations in the studied mechanisms. Nevertheless, the control plasma concentrations of catecholamines and cortisol, the 2 main parameters to determine stress in fish (Donaldson 1981), were close to the lowest values reported in fish (Van Raaij et al. 1996). So, it could be supposed that the impact of cannulation was not significant. The cannulation procedure remains, up to now, the best approach to study
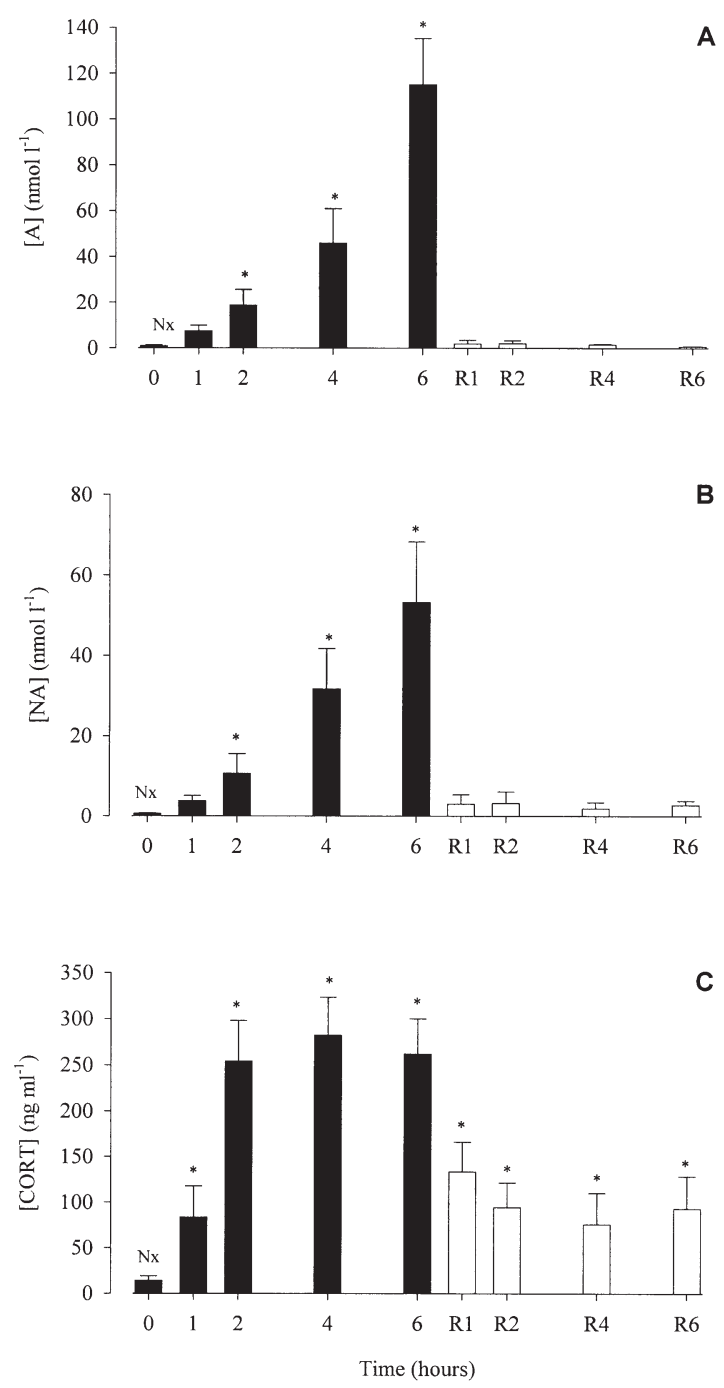

Fig. 2. Plasma adrenaline [A], noradrenaline [NA] and cortisol [CORT] concentrations measured on cannulated fish at time 0 ( $\mathrm{Nx}=$ normoxia), 1, 2, 4 and $6 \mathrm{~h}$ during the exposure at $30 \mathrm{~mm}$ $\mathrm{Hg}(\boldsymbol{\square})$, and 1, 2, 4 and $6 \mathrm{~h}$ after the end of hypoxia ( $\square$ ). Means $\pm \mathrm{SE}(\mathrm{n}=18$ at $t=0$ and $6 \mathrm{~h}$ at the other sample times for cortisol; $\mathrm{n}=12$ at $t=0$ and $4 \mathrm{~h}$ at the other sample times for adrenaline and noradrenaline). *Values significantly different from control data at $\mathrm{p}<0.05$ 

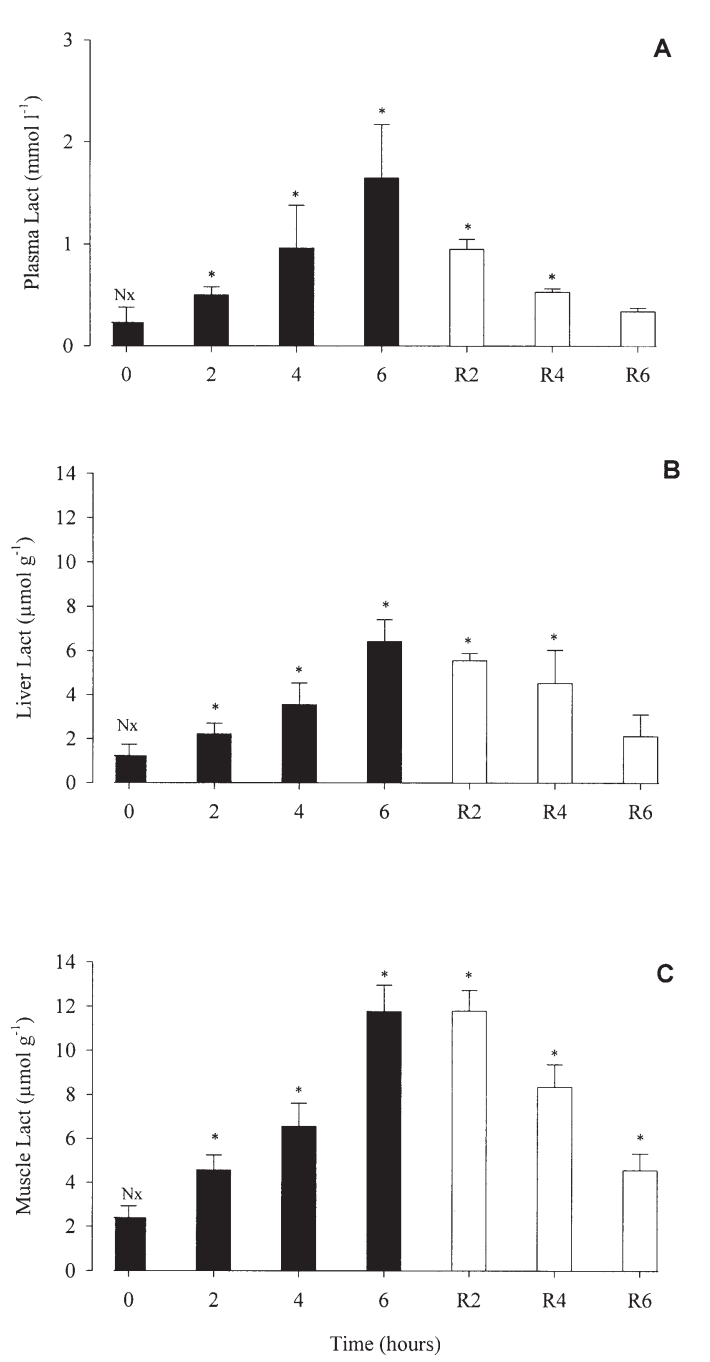

Fig. 3. Plasma, liver and muscle lactate (Lact) concentrations measured on uncannulated fish at time $0(\mathrm{Nx}=$ normoxia $), 2$, 4 and $6 \mathrm{~h}$ during the exposure at $30 \mathrm{~mm} \mathrm{Hg}(\mathbf{\square})$, and 2, 4 and $6 \mathrm{~h}$ after the end of hypoxia ( $\square$ ). Means $\pm \mathrm{SE}(\mathrm{n}=18$ at $t=0$ and $6 \mathrm{~h}$ at the other sample times). *Values significantly different from control data at $\mathrm{p}<0.05$

metabolic and hormonal changes during time without the interference of handling stress. Moreover, to investigate the effect of repeated blood sampling on the measured parameters, blood samples were taken on a lot of 4 normoxic turbot with the sampling procedure used for experimental fish. As no significant difference was observed, it could be concluded that the impact of multiple sampling did not affect the experimental results. When blood parameters measurements and determination of metabolites in muscle and liver were combined, it was necessary to use a procedure including handling, caudal punction, dissection and freezeclamping of tissues. In these uncannulated fish, measured parameters in control samples were close to values reported in carp (Van Ginneken 1998). More- over, the liver and muscle adenylate energy charges in control samples were higher than 0.8 , indicating the absence of tissues damage during sampling (Atkinson 1968).

Three hypoxia levels can be established: (1) slight hypoxia $(90 \mathrm{~mm} \mathrm{Hg}$ ) without any effects on measured parameters; (2) moderate hypoxia $(60 \mathrm{~mm} \mathrm{Hg}$ ) inducing a decrease in $\mathrm{PaO}_{2}$ and a slight increase in muscle lactate concentrations; and (3) severe hypoxia $(30 \mathrm{~mm}$ $\mathrm{Hg}$ ) with marked hormonal and metabolic perturbations.

In fish, the transport of oxygen from water to cell is in part controlled by the oxygen tension difference at each step of respiration (Dejours 1981). $\mathrm{PaO}_{2}$ obtained under control conditions in turbot was close to the data reported in the same species (Perry et al. 1996) and in another flatfish, starry flounder Platichtys stellatus (Wood et al. 1979). This low arterial oxygen partial pressure, compared to values reported in salmonids (Maxime et al. 1991), could explain the absence of metabolic and hormonal perturbations under slight hypoxia. This result suggests that the oxygen tension difference between inspired water and arterial blood is sufficient to maintain the oxygen supply to the tissues when fish were exposed to $90 \mathrm{~mm} \mathrm{Hg}$.

In a previous study (Maxime et al. 2000), an increase in amplitude and frequency of ventilation was observed in turbot exposed for $1 \mathrm{~h}$ to $60 \mathrm{~mm} \mathrm{Hg}$. This hyperventilation contributes to maintain the oxygen supply to the tissues by increasing the availability of oxygen at the gill surface (Lomholt \& Johansen 1979, Glass et al. 1990). In the present study, only $\mathrm{PaO}_{2}$ and muscle lactate concentrations were affected by exposure of turbot to $60 \mathrm{~mm} \mathrm{Hg}$. The increase in muscle lactate concentration indicates undoubtedly the activation of anaerobic metabolism. These results as a whole suggest that during moderate hypoxia the supply of oxygen to the tissues was probably mainly monitored by an increase in ventilation. Similar observations were made on rainbow trout Salmo gairdneri (Soivio et al. 1981), red grouper Epinephelus akaara and black sea bream Mylio macrocephalus (Woo \& Wu 1984). However, due to the additional energetic cost of increased ventilation, this mechanism could not be maintained over a long time. The use of hyperventilation concomitantly with the activation of anaerobic metabolism could be a way to maintain the oxygen supply to the tissues throughout several hours of exposure to moderate hypoxia.

During exposure to severe hypoxia (30 mm Hg), concomitantly with the decrease in $\mathrm{PaO}_{2}$, a marked increase in plasma adrenaline, noradrenaline and cortisol concentrations was observed. The increase in plasma cortisol concentrations following deep hypoxia has been previously reported in most fish species 
studied (Van Raaij et al. 1996, Van Ginneken et al. 1998). Release of catecholamines from chromaffin tissues stimulated by a decrease in $\mathrm{PaO}_{2}$ following deep hypoxia was also reported in many fish species. These hormones are involved in most adaptative mechanisms developed by fish to maintain oxygen supply to the tissues under environmental hypoxia (Aota et al. 1990, Perry et al. 1991, Perry \& Reid 1992, Reid et al. 1998).

The present results suggest a significant role of catecholamines in ventilation control under deep hypoxia as was also reported in rainbow trout (Aota et

Table 3. Plasma, liver and muscle lactate (Lact) concentrations measured on cannulated fish at time 0 (normoxia), 2, 4 and $6 \mathrm{~h}$ during the exposure at 90 and $60 \mathrm{~mm} \mathrm{Hg}$, and 2, 4 and $6 \mathrm{~h}$ after the end of hypoxia (R2, R4 and R6). Means $\pm \mathrm{SE}$ ( $\mathrm{n}=18$ at $t=0$ and $6 \mathrm{~h}$ at the other sample times). ${ }^{*}$ Values significantly different from control data at $\mathrm{p}<0.05$. NS $=$ no significant difference and $\mathrm{S}=$ significant difference

\begin{tabular}{|c|c|c|c|c|c|c|c|c|}
\hline Time (h): & 0 & 2 & 4 & 6 & $\mathrm{R} 2$ & $\mathrm{R} 4$ & R6 & \\
\hline \multicolumn{9}{|l|}{$90 \mathrm{~mm} \mathrm{Hg}$} \\
\hline $\begin{array}{l}\text { Plasma Lact } \\
\left(\mathrm{mmol} \mathrm{l}^{-1}\right)\end{array}$ & $\begin{array}{r}0.26 \\
\pm 0.07\end{array}$ & $\begin{array}{r}0.16 \\
\pm 0.03\end{array}$ & $\begin{array}{r}0.17 \\
\pm 0.03\end{array}$ & $\begin{array}{r}0.15 \\
\pm 0.03\end{array}$ & $\begin{array}{r}0.18 \\
\pm 0.02\end{array}$ & $\begin{array}{r}0.26 \\
\pm 0.05\end{array}$ & $\begin{array}{r}0.27 \\
\pm 0.01\end{array}$ & NS \\
\hline $\begin{array}{l}\text { Liver Lact } \\
\left(\mu \mathrm{mol} \mathrm{g}{ }^{-1}\right)\end{array}$ & $\begin{array}{r}1.30 \\
\pm 0.45\end{array}$ & $\begin{array}{r}1.62 \\
\pm 0.47\end{array}$ & $\begin{array}{r}1.24 \\
\pm 0.69\end{array}$ & $\begin{array}{r}1.51 \\
\pm 0.24\end{array}$ & $\begin{array}{r}1.47 \\
\pm 0.47\end{array}$ & $\begin{array}{r}1.65 \\
\pm 0.54\end{array}$ & $\begin{array}{r}1.74 \\
\pm 0.26\end{array}$ & NS \\
\hline $\begin{array}{l}\text { Muscle Lact } \\
\left(\mu \mathrm{mol} \mathrm{g}{ }^{-1}\right)\end{array}$ & $\begin{array}{r}2.39 \\
\pm 0.54\end{array}$ & $\begin{array}{r}1.89 \\
\pm 0.98\end{array}$ & $\begin{array}{r}2.35 \\
\pm 0.54\end{array}$ & $\begin{array}{r}1.65 \\
\pm 0.63\end{array}$ & $\begin{array}{r}2.12 \\
\pm 0.57\end{array}$ & $\begin{array}{r}2.65 \\
\pm 0.65\end{array}$ & $\begin{array}{r}2.47 \\
\pm 0.78\end{array}$ & NS \\
\hline \multicolumn{9}{|l|}{$60 \mathrm{~mm} \mathrm{Hg}$} \\
\hline $\begin{array}{l}\text { Plasma Lact } \\
\left(\mathrm{mmol} \mathrm{l}^{-1}\right)\end{array}$ & $\begin{array}{r}0.26 \\
\pm 0.07\end{array}$ & $\begin{array}{r}0.29 \\
\pm 0.06\end{array}$ & $\begin{array}{r}0.16 \\
\pm 0.01\end{array}$ & $\begin{array}{r}0.56 \\
\pm 0.02\end{array}$ & $\begin{array}{r}0.28 \\
\pm 0.01\end{array}$ & $\begin{array}{r}0.24 \\
\pm 0.01\end{array}$ & $\begin{array}{r}0.31 \\
\pm 0.03\end{array}$ & NS \\
\hline $\begin{array}{l}\text { Liver Lact } \\
\left(\mu \mathrm{mol} \mathrm{g}^{-1}\right)\end{array}$ & $\begin{array}{r}1.30 \\
\pm 0.45\end{array}$ & $\begin{array}{r}2.21 \\
\pm 0.62\end{array}$ & $\begin{array}{r}2.54 \\
\pm 0.85\end{array}$ & $\begin{array}{r}2.89 \\
\pm 0.34\end{array}$ & $\begin{array}{r}2.84 \\
\pm 0.52\end{array}$ & $\begin{array}{r}2.95 \\
\pm 0.85\end{array}$ & $\begin{array}{r}1.69 \\
\pm 0.24\end{array}$ & NS \\
\hline $\begin{array}{l}\text { Muscle Lact } \\
\left(\mu \mathrm{mol} \mathrm{g}{ }^{-1}\right)\end{array}$ & $\begin{array}{r}2.39 \\
\pm 0.54\end{array}$ & $\begin{array}{r}3.15 \\
\pm 0.69\end{array}$ & $\begin{array}{r}4.25^{*} \\
\pm 0.98\end{array}$ & $\begin{array}{r}4.53^{*} \\
\pm 0.34\end{array}$ & $\begin{array}{r}4.52^{*} \\
\pm 0.64\end{array}$ & $\begin{array}{r}3.45 \\
\pm 0.58\end{array}$ & $\begin{array}{r}2.54 \\
\pm 0.52\end{array}$ & S \\
\hline
\end{tabular}

Table 4. Plasma, liver and muscle glucose (Gluc) concentrations measured on uncannulated fish at time 0 (normoxia), 2,4 and $6 \mathrm{~h}$ during the exposure at 90,60 and $30 \mathrm{~mm} \mathrm{Hg}$, and 2, 4 and $6 \mathrm{~h}$ after the end of hypoxia (R2, R4 and R6). Means $\pm \mathrm{SE}$ (n = 18 at $t=0$ and $6 \mathrm{~h}$ at the other sample times). ${ }^{*}$ Values significantly different from control data at $\mathrm{p}<0.05$. NS $=$ no significant difference and $\mathrm{S}=$ significant difference

\begin{tabular}{|c|c|c|c|c|c|c|c|c|}
\hline Time (h): & 0 & 2 & 4 & 6 & $\mathrm{R} 2$ & $\mathrm{R} 4$ & R6 & \\
\hline \multicolumn{9}{|l|}{90 mm Hg } \\
\hline $\begin{array}{l}\text { Plasma Gluc } \\
\left(\mathrm{mmol} \mathrm{l}^{-1}\right)\end{array}$ & $\begin{array}{r}1.56 \\
\pm 0.21\end{array}$ & $\begin{array}{r}1.47 \\
\pm 0.13\end{array}$ & $\begin{array}{r}1.69 \\
\pm 0.14\end{array}$ & $\begin{array}{r}1.67 \\
\pm 0.30\end{array}$ & $\begin{array}{r}1.34 \\
\pm 0.19\end{array}$ & $\begin{array}{r}1.86 \\
\pm 0.23\end{array}$ & $\begin{array}{r}1.76 \\
\pm 0.27\end{array}$ & NS \\
\hline $\begin{array}{l}\text { Liver Gluc } \\
\left(\mu \mathrm{mol} \mathrm{g}{ }^{-1}\right)\end{array}$ & $\begin{array}{r}1.70 \\
\pm 0.43\end{array}$ & $\begin{array}{r}1.42 \\
\pm 0.31\end{array}$ & $\begin{array}{r}1.75 \\
\pm 0.47\end{array}$ & $\begin{array}{r}1.63 \\
\pm 0.61\end{array}$ & $\begin{array}{r}1.54 \\
\pm 0.61\end{array}$ & $\begin{array}{r}1.68 \\
\pm 0.41\end{array}$ & $\begin{array}{r}1.73 \\
\pm 0.47\end{array}$ & NS \\
\hline $\begin{array}{l}\text { Muscle Gluc } \\
\left.(\mu \mathrm{mol} \mathrm{g})^{-1}\right)\end{array}$ & $\begin{array}{r}0.64 \\
\pm 0.16\end{array}$ & $\begin{array}{r}0.74 \\
\pm 0.13\end{array}$ & $\begin{array}{r}0.59 \\
\pm 0.14\end{array}$ & $\begin{array}{r}0.56 \\
\pm 0.13\end{array}$ & $\begin{array}{r}0.54 \\
\pm 0.17\end{array}$ & $\begin{array}{r}0.76 \\
\pm 0.16\end{array}$ & $\begin{array}{r}0.65 \\
\pm 0.14\end{array}$ & NS \\
\hline $\begin{array}{l}\mathbf{6 0} \mathbf{~ m m ~ H g} \\
\text { Plasma Gluc) } \\
\left(\mathrm{mmol} \mathrm{l}^{-1}\right.\end{array}$ & $\begin{array}{r}1.56 \\
\pm 0.21\end{array}$ & $\begin{array}{r}1.69 \\
\pm 0.36\end{array}$ & $\begin{array}{r}1.89 \\
\pm 0.21\end{array}$ & $\begin{array}{r}1.98 \\
\pm 0.27\end{array}$ & $\begin{array}{r}1.98 \\
\pm 0.17\end{array}$ & $\begin{array}{r}1.84 \\
\pm 0.16\end{array}$ & $\begin{array}{r}1.63 \\
\pm 0.15\end{array}$ & NS \\
\hline $\begin{array}{l}\text { Liver Gluc } \\
\left(\mu \mathrm{mol} \mathrm{g}{ }^{-1}\right)\end{array}$ & $\begin{array}{r}1.70 \\
\pm 0.43\end{array}$ & $\begin{array}{r}1.47 \\
\pm 0.63\end{array}$ & $\begin{array}{r}1.69 \\
\pm 0.27\end{array}$ & $\begin{array}{r}1.78 \\
\pm 0.05\end{array}$ & $\begin{array}{r}1.84 \\
\pm 0.42\end{array}$ & $\begin{array}{r}1.63 \\
\pm 0.16\end{array}$ & $\begin{array}{r}1.75 \\
\pm 0.41\end{array}$ & NS \\
\hline $\begin{array}{l}\text { Muscle Gluc } \\
\left.(\mu \mathrm{mol} \mathrm{g})^{-1}\right)\end{array}$ & $\begin{array}{r}0.64 \\
\pm 0.16\end{array}$ & $\begin{array}{r}0.64 \\
\pm 0.14\end{array}$ & $\begin{array}{r}0.75 \\
\pm 0.20\end{array}$ & $\begin{array}{r}0.57 \\
\pm 0.21\end{array}$ & $\begin{array}{r}0.67 \\
\pm 0.14\end{array}$ & $\begin{array}{r}0.61 \\
\pm 0.16\end{array}$ & $\begin{array}{r}0.54 \\
\pm 0.19\end{array}$ & NS \\
\hline \multicolumn{9}{|l|}{30 mm Hg } \\
\hline $\begin{array}{l}\text { Plasma Gluc } \\
\left(\mathrm{mmol} \mathrm{l}^{-1}\right)\end{array}$ & $\begin{array}{r}1.56 \\
\pm 0.21\end{array}$ & $\begin{array}{r}1.95 \\
\pm 0.26\end{array}$ & $\begin{array}{l}2.53^{*} \\
\pm 0.45\end{array}$ & $\begin{array}{l}2.43^{*} \\
\pm 0.47\end{array}$ & $\begin{array}{r}1.96 \\
\pm 0.16\end{array}$ & $\begin{array}{r}1.65 \\
\pm 0.27\end{array}$ & $\begin{array}{r}1.67 \\
\pm 0.19\end{array}$ & $\mathrm{~S}$ \\
\hline $\begin{array}{l}\text { Liver Gluc } \\
\left(\mu \mathrm{mol} \mathrm{g} \mathrm{g}^{-1}\right)\end{array}$ & $\begin{array}{r}1.70 \\
\pm 0.43\end{array}$ & $\begin{array}{r}1.63 \\
\pm 0.24\end{array}$ & $\begin{array}{r}1.57 \\
\pm 0.34\end{array}$ & $\begin{array}{r}2.16 \\
\pm 0.41\end{array}$ & $\begin{array}{r}1.85 \\
\pm 0.41\end{array}$ & $\begin{array}{r}1.63 \\
\pm 0.42\end{array}$ & $\begin{array}{r}1.74 \\
\pm 0.51\end{array}$ & NS \\
\hline $\begin{array}{l}\text { Muscle Gluc } \\
\left.(\mu \mathrm{mol} \mathrm{g})^{-1}\right)\end{array}$ & $\begin{array}{r}0.64 \\
\pm 0.16\end{array}$ & $\begin{array}{r}0.62 \\
\pm 0.26\end{array}$ & $\begin{array}{r}0.58 \\
\pm 0.18\end{array}$ & $\begin{array}{r}0.69 \\
\pm 0.16\end{array}$ & $\begin{array}{r}0.65 \\
\pm 0.12\end{array}$ & $\begin{array}{r}0.49 \\
\pm 0.16\end{array}$ & $\begin{array}{r}0.54 \\
\pm 0.12\end{array}$ & NS \\
\hline
\end{tabular}


Table 5. Liver and muscle glycogen (Glyc) concentrations ( $\mu \mathrm{mol} \mathrm{g}{ }^{-1}$ ) measured on uncannulated fish at time 0 (normoxia), 2,4 and $6 \mathrm{~h}$ during the exposure at 90,60 and $30 \mathrm{~mm} \mathrm{Hg}$, and 2, 4 and $6 \mathrm{~h}$ after the end of hypoxia (R2, R4 and R6). Means $\pm \mathrm{SE}$ (n = 18 at $t=0$ and $6 \mathrm{~h}$ at the other sample times). ${ }^{*}$ Values significantly different from control data at $\mathrm{p}<0.05$. NS $=$ no significant difference and $\mathrm{S}=$ significant difference

\begin{tabular}{|c|c|c|c|c|c|c|c|c|}
\hline Time (h): & 0 & 2 & 4 & 6 & $\mathrm{R} 2$ & $\mathrm{R} 4$ & R6 & \\
\hline \multicolumn{9}{|l|}{$90 \mathrm{~mm} \mathrm{Hg}$} \\
\hline Liver Glyc & $\begin{array}{r}287 \\
\pm 119\end{array}$ & $\begin{array}{r}269 \\
\pm 98\end{array}$ & $\begin{array}{r}321 \\
\pm 152\end{array}$ & $\begin{array}{r}274 \\
\pm 141\end{array}$ & $\begin{array}{r}296 \\
\pm 123\end{array}$ & $\begin{array}{r}266 \\
\pm 147\end{array}$ & $\begin{array}{r}230 \\
\pm 152\end{array}$ & NS \\
\hline Muscle Glyc & $\begin{array}{r}76 \\
\pm 40\end{array}$ & $\begin{array}{r}71 \\
\pm 34\end{array}$ & $\begin{array}{r}78 \\
\pm 29\end{array}$ & $\begin{array}{r}64 \\
\pm 28\end{array}$ & $\begin{array}{r}76 \\
\pm 37\end{array}$ & $\begin{array}{r}67 \\
\pm 37\end{array}$ & $\begin{array}{r}72 \\
\pm 36\end{array}$ & NS \\
\hline \multicolumn{9}{|l|}{$60 \mathrm{~mm} \mathrm{Hg}$} \\
\hline Liver Glyc & $\begin{array}{r}287 \\
\pm 119\end{array}$ & $\begin{array}{r}296 \\
\pm 123\end{array}$ & $\begin{array}{r}314 \\
\pm 124\end{array}$ & $\begin{array}{r}247 \\
\pm 96\end{array}$ & $\begin{array}{r}285 \\
\pm 124\end{array}$ & $\begin{array}{r}304 \\
\pm 150\end{array}$ & $\begin{array}{r}274 \\
\pm 94\end{array}$ & NS \\
\hline Muscle Glyc & $\begin{array}{r}76 \\
\pm 40\end{array}$ & $\begin{array}{r}74 \\
\pm 30\end{array}$ & $\begin{array}{r}85 \\
+42\end{array}$ & $\begin{array}{r}82 \\
\pm 34\end{array}$ & $\begin{array}{r}71 \\
+26\end{array}$ & $\begin{array}{r}76 \\
\pm 28\end{array}$ & $\begin{array}{r}69 \\
\pm 32\end{array}$ & NS \\
\hline $30 \mathrm{~mm} \mathrm{Hg}$ & & & & & & & & \\
\hline Liver Glyc & $\begin{array}{r}287 \\
\pm 79\end{array}$ & $\begin{array}{r}290 \\
\pm 98\end{array}$ & $\begin{array}{r}247 \\
\pm 80\end{array}$ & $\begin{array}{r}125^{*} \\
\pm 50\end{array}$ & $\begin{array}{r}183 \\
\pm 78\end{array}$ & $\begin{array}{r}247 \\
\pm 98\end{array}$ & $\begin{array}{r}212 \\
\pm 53\end{array}$ & S \\
\hline Muscle Glyc & $\begin{array}{r}76 \\
\pm 40\end{array}$ & $\begin{array}{r}59 \\
\pm 21\end{array}$ & $\begin{array}{r}75 \\
\pm 31\end{array}$ & $\begin{array}{r}82 \\
\pm 26\end{array}$ & $\begin{array}{r}79 \\
\pm 36\end{array}$ & $\begin{array}{r}64 \\
\pm 29\end{array}$ & $\begin{array}{r}86 \\
\pm 48\end{array}$ & NS \\
\hline
\end{tabular}

Table 6. Liver and muscle adenylate energy charge (AEC) measured on uncannulated fish at time 0 (normoxia), 2, 4 and 6 h during the exposure at 90,60 and $30 \mathrm{~mm} \mathrm{Hg}$, and 2, 4 and $6 \mathrm{~h}$ after the end of hypoxia (R2, R4 and R6). Means \pm SE (n $=18$ at $t=0$ and $6 \mathrm{~h}$ at the other sample times). NS = no significant difference

\begin{tabular}{|c|c|c|c|c|c|c|c|c|}
\hline Time (h): & 0 & 2 & 4 & 6 & $\mathrm{R} 2$ & $\mathrm{R} 4$ & $\mathrm{R} 6$ & \\
\hline $\begin{array}{l}\mathbf{9 0} \mathbf{~ m m ~} \mathbf{~ H g} \\
\text { Liver AEC }\end{array}$ & $\begin{array}{r}0.86 \\
\pm 0.11\end{array}$ & $\begin{array}{r}0.87 \\
\pm 0.05\end{array}$ & $\begin{array}{r}0.87 \\
\pm 0.04\end{array}$ & $\begin{array}{r}0.87 \\
\pm 0.02\end{array}$ & $\begin{array}{r}0.88 \\
\pm 0.04\end{array}$ & $\begin{array}{r}0.89 \\
\pm 0.03\end{array}$ & $\begin{array}{r}0.84 \\
\pm 0.04\end{array}$ & NS \\
\hline Muscle AEC & $\begin{array}{r}0.94 \\
\pm 0.14\end{array}$ & $\begin{array}{r}0.94 \\
\pm 0.08\end{array}$ & $\begin{array}{r}0.95 \\
\pm 0.07\end{array}$ & $\begin{array}{r}0.95 \\
\pm 0.06\end{array}$ & $\begin{array}{r}0.94 \\
\pm 0.05\end{array}$ & $\begin{array}{r}0.94 \\
\pm 0.04\end{array}$ & $\begin{array}{r}0.94 \\
\pm 0.08\end{array}$ & NS \\
\hline $\begin{array}{l}\mathbf{6 0} \mathbf{~ m m ~ H g} \\
\text { Liver AEC }\end{array}$ & $\begin{array}{r}0.86 \\
\pm 0.11\end{array}$ & $\begin{array}{r}0.88 \\
\pm 0.09\end{array}$ & $\begin{array}{r}0.86 \\
\pm 0.08\end{array}$ & $\begin{array}{r}0.87 \\
\pm 0.07\end{array}$ & $\begin{array}{r}0.90 \\
\pm 0.08\end{array}$ & $\begin{array}{r}0.88 \\
\pm 0.12\end{array}$ & $\begin{array}{r}0.86 \\
\pm 0.14\end{array}$ & NS \\
\hline Muscle AEC & $\begin{array}{r}0.94 \\
\pm 0.14\end{array}$ & $\begin{array}{r}0.94 \\
\pm 0.23\end{array}$ & $\begin{array}{r}0.95 \\
\pm 0.19\end{array}$ & $\begin{array}{r}0.95 \\
\pm 0.10\end{array}$ & $\begin{array}{r}0.94 \\
\pm 0.11\end{array}$ & $\begin{array}{r}0.94 \\
\pm 0.05\end{array}$ & $\begin{array}{r}0.94 \\
\pm 0.09\end{array}$ & NS \\
\hline $\begin{array}{l}\mathbf{3 0} \mathbf{~ m m ~ H g} \\
\text { Liver AEC }\end{array}$ & $\begin{array}{r}0.86 \\
\pm 0.11\end{array}$ & $\begin{array}{r}0.85 \\
\pm 0.13\end{array}$ & $\begin{array}{r}0.87 \\
\pm 0.09\end{array}$ & $\begin{array}{r}0.83 \\
\pm 0.15\end{array}$ & $\begin{array}{r}0.87 \\
\pm 0.14\end{array}$ & $\begin{array}{r}0.89 \\
\pm 0.16\end{array}$ & $\begin{array}{r}0.89 \\
\pm 0.17\end{array}$ & NS \\
\hline Muscle AEC & $\begin{array}{r}0.94 \\
\pm 0.14\end{array}$ & $\begin{array}{r}0.94 \\
\pm 0.13\end{array}$ & $\begin{array}{r}0.93 \\
\pm 0.09\end{array}$ & $\begin{array}{r}0.94 \\
\pm 0.11\end{array}$ & $\begin{array}{r}0.94 \\
\pm 0.10\end{array}$ & $\begin{array}{r}0.942 \\
\pm 0.1\end{array}$ & $\begin{array}{r}0.94 \\
\pm 0.13\end{array}$ & NS \\
\hline
\end{tabular}

al. 1990). Indeed, as previously described (Maxime et al. 2000), when exposed to $30 \mathrm{~mm} \mathrm{Hg}$, turbot resorted to an increase of ventilation leading to a respiratory alkalosis (+ $0.11 \mathrm{pH}$ in this study). In this case, hyperventilation did not appear to be efficient enough to maintain the oxygen supply to the tissues. Turbot resorted to anaerobic metabolism, resulting in lactate production and, as a consequence, in a marked decrease in arterial $\mathrm{pH}$. Such a response was observed in most fish species, such as flounder (Jorgensen \& Mustafa 1980), european eel Anguilla anguilla (Van
Waarde 1983), sole (Dalla Via et al. 1994), and carp Cyprinus carpio (Van Ginneken et al. 1998).

In fish, part of blood lactate originates from muscle glycogen, as uptake rates of blood glucose in fish are low due to the slow transport of glucose across the membrane and to the low activity of hexokinase in peripheral tissues (Johnston \& Moon 1979, Knox et al. 1980). However, in this study, despite the increase in muscle lactate concentrations, no significant change in muscle glycogen content was observed. In this experiment, in turbot, another part of blood lactate was pro- 
duced from the liver glycogen pool, as indicated by a marked glycogen depletion observed in this tissue associated with the high lactate levels during severe hypoxia. A similar response was reported in flounder by Jorgensen \& Mustafa (1980). Hypoxia induces contradictory effects on blood lactate levels in fish. In hypoxic rainbow trout, the major part of lactate was retained in white muscle tissue (Dunn \& Hochachka 1986), whereas such a retention of lactate was absent in carp (Driedzic \& Hochachka 1975) and sole (Dalla Via et al. 1994). In turbot, the possibility of retention of a large part of lactate in muscle despite the continuous lactate diffusion from muscle fibers to blood was put forward (Maxime et al. 2000). During the exposure to severe hypoxia, the slight increase in plasma lactate compared to the increase in muscle lactate observed in this study has confirmed this hypothesis. Retention of lactate in muscle could be due to a peripheral vasoconstriction mediated by catecholamines (Wardle 1978). During recovery, blood, liver and muscle lactate concentrations remained at a high level, and several hours were required for lactate to return to control levels. Lactate produced under hypoxia would be mainly metabolized in situ in muscle or liver by glucogenesis or oxidation, the relative contribution of both processes being unknown (Scarabello et al. 1991).

In turbot, exposure to severe hypoxia has also been shown to induce significant hyperglycemia as in most fish species, such as flounder (Jorgensen \& Mustafa 1980), carp and rainbow trout (Van Raaij et al. 1996). Although no change in glucose liver concentration was observed throughout the hypoxic period in this study, part of liver glycogen could be metabolized to glucose which was immediately transferred to the blood as only the liver could enzymatically release glucose in significant amounts (Johnston \& Moon 1979). Moreover, in fish, glycogenolysis has been shown to account for the major part of the hepatic glucose production whereas gluconeogenesis plays a minor role during exposure to deep hypoxia (Dunn \& Hochachka 1986, Janssens \& Waterman 1986, Mommsen et al. 1988). In fish, liver glycogenolysis can be stimulated by catecholamines which inhibit the pyruvate kinase activity and simul-taneously activate the glycogen phosphorylase (Janssens \& Waterman 1986, Mommsen et al. 1988). During the exposure to severe hypoxia, hyperglycemia was concomitant with the large increase in adrenaline and the slight increase in noradrenaline. As these 2 hormones could stimulate hepatic glycogenolysis (Sheridan \& Muir 1988), the hyperglycemia observed in turbot could be mainly due to the adrenergic stimulation of hepatic glycogenolysis.

Throughout exposure to severe hypoxia, no change in nucleotide contents (ATP, ADP, AMP and IMP) was observed in turbot liver and muscle. Therefore, in tur- bot, unlike sole (Dalla Via et al. 1994), no metabolic depression (decrease in total ATP production) was observed during exposure to severe hypoxia. The anaerobic ATP production appears efficient enough to compensate for the loss of energy production by the aerobic metabolism when fish were exposed to deep hypoxia. ATP production could also be stabilized by the buffer capacity of the phosphocreatine pool, a storage reservoir of chemical energy in vertebrate muscles (Dalla Via et al. 1994, Van Den Thillart \& Van Raaij 1995).

The adenylate energy charge (AEC) is an important regulatory factor in energy metabolism (Atkinson 1968). In turbot, normoxic values of AEC observed in white muscle are close to values reported in previous studies on goldfish Carassius auratus (Van Den Thillart et al. 1976), flounder (Jorgensen \& Mustafa 1980) and rainbow trout (Caldwell \& Hinshaw 1994). Normoxic values of liver AEC measured in turbot are higher than those previously determined in flounder (Jorgensen \& Mustafa 1980), goldfish (Van den Thillart et al. 1980) and eel (Van Waarde et al. 1983). In the present study, no change in AEC in both the liver and muscle was observed throughout the exposure to severe hypoxia. This result indicates the high efficiency of anaerobic glycogenolysis in maintaining the ATP production in turbot exposed to deep hypoxia.

In this study, an increase in hematocrit was also observed during exposure to severe hypoxia. Two hypotheses could be put forward to explain this result: (1) An increase in erythrocyte release due to spleen contraction stimulated by catecholamines as previously shown in the antarctic fish Pagothenia borchgrevinky (Wells et al. 1989) and in rainbow trout (Wells \& Weber 1990). (2) An increase in erythrocyte volume due to the adrenergic activation of $\mathrm{Na}^{+} / \mathrm{H}^{+}$exchange mechanism across the cell membrane; if this was the case, the subsequent increase in intracellular $\mathrm{pH}$ could enhance hemoglobin oxygen affinity (Mahé et al. 1985, Borgese et al. 1986). These 2 mechanisms could contribute to facilitate oxygen transport to tissues as a compensation of the decrease in oxygen availability. Further investigations are necessary to confirm these hypotheses.

As a conclusion to this study, it could be confirmed that turbot is able to develop high adaptative mechanisms to face hypoxic environmental conditions. This high capacity to cope with low water $\mathrm{O}_{2}$ tension could be related to its way of life. Turbot, like sole (Dalla Via et al. 1998), is a benthic flatfish, and when exposed to hypoxic areas from which they cannot escape they are unable to sustain a high swimming activity. Therefore, this species has had to develop a wide range of physiological adaptative strategies to face hypoxia. 
Acknowledgements. This investigation was supported by a grant from IFREMER. The authors thank N. Le Bayon and L. Quéméner for technical assistance, A. Le Roux and A. Sévère for cortisol measurements, and Dr P. Soulier and M. J. Lepioufle for their careful and critical reading of the manuscript.

\section{LITERATURE CITED}

Adcock PJ, Dando PR (1983) White muscle lactate and pyruvate concentrations in rested flounder, Platichthys flesus and plaice, Pleuronectes platessa: a re-evaluation of handling and sampling techniques. J Mar Biol Assoc UK 63:897-903

Aota S, Holmgren KD, Gallaugher P, Randall DJ (1990) A possible role for catecholamines in the ventilatory responses associated with the internal acidosis or external hypoxia in rainbow trout, Oncorhynchus mykiss. J Exp Biol 151: $57-68$

Atkinson DE (1968) The energy charge of the adenylate pool as a regulatory parameter. Interaction with feedback modifiers. Biochem J 7:4030-4034

Borgese F, Garcia-Romeu F, Motais R (1986) Catecholamineinduced transport systems in trout erythrocyte. $\mathrm{Na}^{+} / \mathrm{H}^{+}$ countertransport or $\mathrm{NaCl}$ cotransport? J Gen Physiol 8: 551-556

Caldwell CA, Hinshaw JM (1994) Nucleotides and the adenymate charge as indicators of stress in rainbow trout (Oncorhynchus mykiss) subjected to a range of dissolved oxygen concentrations. Comp Biochem Physiol 109B: 313-323

Carr RS, Neff JM (1984) Quantitative semi-automated enzymatic assay for tissue glycogen. Comp Biochem Physiol 77B(3):447-449

Dalla Via J, Van Den Thillart G, Cattani O, De Zwaan A (1994) Influence of long-term hypoxia exposure on the energy metabolism of Solea solea. II. intermediary metabolism in blood, liver and muscle. Mar Ecol Prog Ser 111: $17-27$

Dalla Via J, Van den Thillart G, Cattani O, Cortesi P (1998) Behavioural responses and biochemical correlates in Solea solea to gradual hypoxic exposure. Can J Zool 76: $2108-2113$

Dejours P (1981) Principles of comparative respiratory physiology, 2nd edn. Elsevier, Amsterdam, p 265

Donaldson EM (1981) The pituitary interenal axis as an indicator of stress in fish. In: Pickering AD (ed) Stress and fish. Academic Press, London, p 11-47

Driedzic WR, Hochachka PW (1975) The unanswered question of high anaerobic capabilities of carp white muscle. Can J Zool 53:706-712

Dunn JF, Hochachka PW (1986) Metabolic responses of trout (Salmo gairdneri) to acute environmental hypoxia. J Exp Biol 123:229-242

Gaumet F, Boeuf G, Sévère A, Le Roux A, Mayer-Gostan N (1995) Effects of salinity on the ionic balance and growth of juvenile turbot. J Fish Biol 47:865-876

Glass ML, Andersen NA, Kruhoffer M, Williams EM, Heisler $\mathrm{N}$ (1990) Combined effects of environmental $\mathrm{PO}_{2}$ and temperature on ventilation and blood gases in the carp Cyprinus carpio. J Exp Biol 148:1-18

Janssens PA, Waterman J (1986) Hormonal regulation of gluconeogenesis and glycogenolysis in carp (Cyprinus carpio) liver pieces cultured in vitro. Comp Biochem Physiol 91A: 451-455

Johnston IA, Moon TW (1979) Glycolytic and gluconeogenic enzyme activities in the skeletal muscle and liver of a teleost fish (Pleuronectes platessa) Trans Biochem Soc 7: $661-663$

Jorgensen JB, Mustafa T (1980) The effects of hypoxia on carbohydrate metabolism of flounder (Platichthys flesus) I. Utilization of glycogen and accumulation of glycolytic end products in various tissues. Comp Biochem Physiol 67: 243-248

Kinkead R, Perry S (1991) The effects of catecholamines on ventilation in rainbow trout during external hypoxia or hypercapnia. Respir Physiol 84:77-92

Knox D, Walton MJ, Cowey CB (1980) Distribution of enzymes of glycolysis and gluconeogenesis in fish tissues. Mar Biol 56:7-10

Lamers AE, Flik G, Atsma W, Wendelaar Bonga SE (1992) A role of di-acetyl-alpha-melanocyte-stimulating hormone in the control of cortisol release in the teleost Oreochromis mosambicus. J Endocrinol 135:285-292

Letellier S, Garnier JP, Dreux C (1994) Détermination de la LDOPA du DOPAC et des catécholamines dans le plasma par chromatographie liquide haute performance avec détection électrochimique. Act Pharm Biol Clin 7:412-416 (in French with English abstract)

Lomholt JP, Johansen K (1979) Hypoxia acclimation in carphow it affects oxygen uptake, ventilation, and oxygen extraction from water. Physiol Zool 52:38-49

Mahé Y, Garcia-Romeu F, Motais R (1985) Inhibition by amiloride of both adenylate cyclase activity and the $\mathrm{Na}^{+} / \mathrm{H}^{+}$ antiporter in fish erythrocytes. J Exp Biol 116:199-206

Maxime V, Pennec JP, Peyraud C (1991) Effects of direct transfer from freshwater to seawater on respiratory and circulatory variables and acid-base status in rainbow trout. J Comp Physiol 161:557-568

Maxime V, Nonnotte G, Williot P (1998) Adaptations respiratoires et circulatoires de l'esturgeon sibérien à une hypoxie environnementale. Bull Fr Pêche Piscic 350-351: 377-391 (in French with English abstract)

Maxime V, Pichavant K, Nonnotte G, Boeuf G (2000) Effects of hypoxia on respiratory physiology of turbot, Scophthalmus maximus. Fish Physiol Biochem 22(1):51-59

Mazeaud MM, Mazeaud M, Donaldson EM (1977) Primary and secondary effects of stress in fish: some new data with a general review. Trans Am Fish Soc 106:201-212

Mommsen TP, Walsh PJ, Perry SF, Moon TW (1988) Interactive effects of catecholamines and hypercapnia on glucose production in isolated trout hepatocytes. Gen Comp Endocrinol 70:63-73

Nonnotte G, Truchot JP (1990) Time course of extracellular acid-base adjustements under hypo- or hyperosmotic conditions in the euryhaline fish Platichthys flesus. J Fish Biol 36:181-190

Perry SF, Reid SD (1992) Relationships between blood oxygen content and catecholamine levels during hypoxia in rainbow trout and American eel. Am J Physiol 263:R240-R249

Perry SF, Fritsche R, Kinkead R, Nilsson S (1991) Controle of catecholamine release in vivo and in situ in the Atlantic cod (Gadus morhua) during hypoxia. J Exp Biol 155: $549-566$

Perry SF, Wood CM, Walsh PJ, Thomas S (1996) Fish red blood cell carbon dioxide transport in vitro: a comparative study. Comp Biochem Physiol 113(2):121-130

Person-Le-Ruyet J, Baudin-Laurencin F, Devauchelle N, Métailler R, Nicolas JL, Robin J, Guillaume J (1991) Culture of turbot (Scophthalmus maximus). In: McVey JP (ed) CRC Handbook of mariculture, finfish aquaculture, Vol II. CRC Press, Boca Raton, FL, p 77-82

Pichavant $K$, Person-Le-Ruyet J, Le Bayon N, Sévère A and 5 others (2000) Effects of hypoxia on growth and metabolism 
of juvenile turbot. Aquaculture 188:103-114

Reid SG, Bernier NJ, Perry SF (1998) The adrenergic stress response in fish: control of catecholamine storage and release. Comp Biochem Physiol 120C:1-27

Scarabello M, Heigenhauser GJF, Wood CM (1991) The oxygen debt hypothesis in juvenile rainbow trout after exhaustive exercise. Respir Physiol 84:245-259

Sheridan MA, Muir NA (1988) Effects of epinephrine and norepinephrine on glucose release from chinook salmon (Oncorhynchus tshawytscha) liver incubated in vitro. J Exp Zool 248:155-159

Smith MJ, Heath AG (1980) Responses to acute anoxia and prolonged hypoxia by rainbow trout (Salmo gairdneri) and mirror carp (Cyprinus carpio) red and white muscle: use of conventional and modified metabolic pathways. Comp Biochem Physiol 66B:267-272

Soivio A, Nikinmaa M, Westman K (1981) The blood oxygen binding properties of hypoxic Salmo gairdneri. J Comp Physiol 136B:83-87

Van Den Thillart G, Van Raaij M (1995) Endogenous fuels: non invasive versus invasive approaches. Chap 2: Endogenous fuels. In: Hochachka PW, Mommsen TP (eds) Biochemistry and molecular biology of fishes, Vol IV, Metabolic and adaptational biochemistry. Elsevier Science, Amsterdam, p 33-36

Van Den Thillart G, Kesbeke F, Van Waarde A (1976) Influence of anoxia on the energy metabolism of goldfish, Carassius auratus (L.). Comp Biochem Physiol 55A: 329-336

Van Den Thillart G, Kesbeke F, Van Waarde A (1980) Anaerobic energy metabolism of gold fish, Carassius auratus (L.). Influence of hypoxia and anoxia on phosphorylated compounds and glycogen. J Comp Physiol 136:45-52

Van Ginneken VJT, Van Caubergh P, Nieveen M, Balm P,

Editorial responsibility: Otto Kinne (Editor),

Oldendorf/Luhe, Germany
Van Den Thillart G, Addink A (1998) Influence of hypoxia exposure on the energy metabolism of common carp (Cyprinus carpio L.). Neth J Zool 48(1):65-82

Van Raaij MTM, Van den Thillart GEEJM, Vianen GJ, Pit DSS, Balm PHM, Steffens AB (1996) Substrate mobilization and hormonal changes in rainbow trout (Oncorhynchus mykiss, L.) and common carp (Cyprinus carpio, L.) during deep hypoxia and subsequent recovery. J Comp Physiol 166:443-452

Van Waarde A, Van Den Thillart G, Kesbeke F (1983) Anaerobic energy metabolism of the European eel, Anguilla anguilla L. J Comp Physiol 149:469-475

Van Waversveld J, Addink ADF, Van Den Thillart G (1989) The anaerobic energy metabolism of goldfish measured by simultaneous direct and indirect calorimetry during anoxia and hypoxia. J Comp Physiol 159:263-268

Wardle CS (1978) Non-release of lactic acid from anaerobic swimming muscle of plaice, Pleuronectes platessa L.: a stress reaction. J Exp Biol 77:141-155

Wells RMG, Weber RE (1990) The spleen in hypoxic and exercised rainbow trout. J Exp Biol 103:95-108

Wells RMG, Grigg GC, Beard LA, Summers G (1989) Hypoxic responses in a fish from stable environment: blood oxygen transport in the antartic fish Pagothenia borhgrevinki. J Exp Biol 141:97-111

Woo YS, Wu RSS (1984) Changes in biochemical composition in the red grouper, Epinephelus akaara (Temminck and Schlegel), and the black sea bream, Mylio macrocephalus (Basilewsky), during hypoxic exposure. Comp Biochem Physiol 77A(3):475-482

Wood CM, McMahon BR, McDonald DG (1979) Respiratory gas exchange in the resting starry flounder, Platichthys stellatus: a comparison with other teleosts. J Exp Biol 48:167-179

Submitted: January 23, 2001; Accepted: June 19, 2001 Proofs received from author(s): January 3, 2001 